\title{
Pasture species and drought impacts on milk yield 2. Predicted farm milk yield at four sites
}

\author{
D.J. BARKER, D.A. CLARK ${ }^{1}$, E.R. THOM ${ }^{1}$, J.N. COUCHMAN, \\ R.N. BURTON and N. DYMOCK \\ AgResearch, Grasslands Research Centre, Private Bag 11008, Palmerston North \\ ${ }^{1}$ Dairying Research Corporation, Private Bag 3123, Hamilton
}

\section{Abstract}

A desirable option for increasing milk yield per farm is to increase milk production in summer without compromising peak-season production or the duration of lactation. The dairy industry has a goal to achieve a $4 \%$ per month post-peak decline of milk production. The effect of five pasture types and two summer water regimes on predicted farm milk yield, in Northland, Waikato, Manawatu and Canterbury was measured over 1 year. Two pasture treatments, resident pasture and Grasslands Nui ryegrass, were common to all sites. A third pasture treatment varied between sites: triple mix (Grasslands Advance tall fescue, Grasslands Kara cocksfoot, and Grasslands Maru phalaris) at the Manawatu site; the same triple mix but with Grasslands Raki paspalum at the Northland site; and low-endophyte ryegrass and Grasslands Kahu timothy (LER) at the Canterbury site; all sown treatments included red and white clover. All five pasture types were included at the Waikato site. On average for all pasture types, water deficit reduced summer herbage accumulation (HA) to $79,68,43$ and $18 \%$ of irrigated controls, and annual HA to $88,80,73$ and $63 \%$ of irrigated controls in Northland, Waikato, Manawatu and Canterbury, respectively. Since farm milk yield predicted by UDDER was highly correlated with annual HA $\left(\mathrm{R}^{2}\right.$ $=83 \%$ ), the effects of pasture type and water deficit on milk yield were similar to effects on HA. Seasonal and annual HA differed among the five pasture types at each of the four sites. The most important factor affecting predicted farm milk yield was annual HA, with relatively little effect from the seasonal pattern of pasture growth. Differences in shapes of the predicted milk supply curves for various treatments occurred, particularly when drought forced early drying-off. The best predicted summer milk yield was for the Canterbury irrigated LER pasture treatment, a $6.8 \%$ per month postpeak decline of milk production.

Keywords: farm milk yield, farm system modelling, forage supply, pasture species, water deficit

\section{Introduction}

One option for increasing milk yield per farm is to increase summer milk production without compromising shoulder-season or peak production. An industry objective to reduce the decline in farm milk yield after peak lactation to $4 \%$ per month, could be achieved through increased pasture quantity and/or increased pasture quality. In addition to greater income to producers, milk processors would benefit from the potential for greater efficiency in factory use.

Variation in summer rainfall is the most significant factor causing variability in summer and, therefore, annual pasture production (McAneney et al. 1982; Parfitt et al. 1985), with obvious consequences for farm milk flow. Farms subjected to intermittent drought without the protection of irrigation are certain to suffer intermittent losses in milk production. The impact of drought on pasture and milk yield depends on the extent of water deficit compared with well-watered (irrigated) controls.

The effects of drought can be reduced by using drought-tolerant pasture species such as paspalum, tall fescue, cocksfoot and phalaris (Lambert 1967). These species show better summer production, but at the expense of little winter production from paspalum, poorer herbage quality from cocksfoot and some tall fescue cultivars, and poor persistence in phalaris. Tall fescue, for example, can have double the white clover content of ryegrass pastures without compromising yield (Milne et al. 1997), which could support better summer milk production.

The farm simulation programme UDDER predicts farm milk yield from pasture growth and management inputs (Larcombe 1990). Options allow comparison of the effect of contrasting growth patterns for different pasture species, differences in pasture quality (Thom $e t$ al. 1998) and the effect of drought on farm milk yield. Modelling with UDDER is a useful planning tool before starting large-scale systems trials or planning changes to farm management.

This research measured pasture species and drought impacts on the seasonal distribution of pasture yield and quality, and predicted, using UDDER, the likely impact on farm milk yield. 


\section{Methods}

\section{Sites}

Large ( $>0.1$ ha) plots were sprayed with glyphosate, cultivated and sown with two pasture treatments at each of three sites: Northland (a commercial dairy farm near Kerikeri on a free-draining volcanic soil), Manawatu (a commercial dairy farm at Himatangi on a free-draining sandy soil) and Canterbury (Winchmore Research Station on a free-draining stony soil) during February and March 1996 (Table 1). One pasture treatment, which was common to all sites, was high-endophyte ryegrass (HER). A second pasture treatment, which varied between sites, comprised triple mix (TM) (Grasslands Advance tall fescue, Grasslands Kara cocksfoot and Grasslands Maru phalaris) at the Manawatu site, TM + Grasslands Raki paspalum (TMP) at the Northland site, and low-endophyte ryegrass and Grasslands Kahu timothy (LER) at the Canterbury site; all sown treatments included red clover and white clover (Table 1). A third pasture treatment at each site was uncultivated existing pasture (EP). At a fourth site, Waikato (Dairying Research Corporation, No. 5 Dairy on silt and clay loam soils), all five pasture types were established for measurement of milk yield (Thom et al. 1998) (Table 1). All sites compared dryland pastures against well-watered (irrigated) controls.

Treatments at 3 sites were laid out as a randomised complete block design with three blocks, three pasture types and two water regimes; the Waikato site was a $2 \times$
5 split-plot factorial with two water treatments as main plots, five pasture types as sub-plots and four replicates. Analysis of variance of pasture measurements was performed using the Statistical Analysis System (SAS Institute Inc, NC, USA) to test the main effects (water and pasture type), and the water by pasture type interaction separately for each site. Statistical analysis was not performed on the output from UDDER.

\section{Measurements}

Herbage mass (cover) was measured immediately before and after grazing (by dairy cattle) 7-12 times per year, between approximately August 1996 and August 1997, by cutting (Northland and Canterbury) or calibrated rising plate meter (Waikato and Manawatu). Botanical composition was determined on sub-samples collected before grazing. Herbage accumulation (HA) was calculated as the increase in herbage mass between consecutive grazings. Seasonal and annual HA were calculated by totalling HA for 3- and 12-month periods, respectively, for each plot.

\section{Modelling}

Farm systems were modelled with UDDER (version 8.11) using HA rates (data not shown) measured during the first milking season after establishment (August 1996-July 1997) for three pasture types at three sites (5 pasture types in Waikato) and two water regimes, assuming all the farm area comprised that pasture-water treatment. A common management was used for the 28

Table 1 Pasture treatments, sowing rates, and measurements at four sites.

\begin{tabular}{|c|c|c|c|c|}
\hline Treatments & Northland & Waikato & Manawatu & Canterbury \\
\hline $\begin{array}{l}\text { Existing pasture (EP) } \\
\text { kikuyu-based in Northland; ryegrass-based in Waikato, } \\
\text { Manawatu and Canterbury }\end{array}$ & $\checkmark$ & $\checkmark$ & $\checkmark$ & $\checkmark$ \\
\hline $\begin{array}{l}\text { High-endophyte ryegrass (HER) } \\
\text { G. Nui ryegrass ( } 22 \mathrm{~kg} / \mathrm{ha}) ; \mathrm{G} \text {. Kopu white clover ( } 3 \text { kg/ha) }\end{array}$ & $\checkmark$ & $\checkmark$ & $\checkmark$ & $\checkmark$ \\
\hline $\begin{array}{l}\text { Triple mix + paspalum (TMP) } \\
\text { G. Raki paspalum ( } 4 \mathrm{~kg} / \mathrm{ha}) ; \mathrm{G} \text {. Advance tall fescue }(12 \mathrm{~kg} / \mathrm{ha}) \text {; } \\
\text { G. Kara cocksfoot }(2 \mathrm{~kg} / \mathrm{ha}) ; \mathrm{G} \text {. Maru phalaris }(1 \mathrm{~kg} / \mathrm{ha}) ; \mathrm{G} \text {. Kopu } \\
\text { G. Prestige white clovers }(1.5 \mathrm{~kg} / \mathrm{ha} \text { each); G. Colenso red clover }\end{array}$ & $\checkmark$ & $\checkmark$ & & \\
\hline $\begin{array}{l}\text { Triple mix (TM) } \\
\text { G. Advance tall fescue ( } 22 \mathrm{~kg} / \mathrm{ha}) ; \mathrm{G} \text {. Maru phalaris }(3 \mathrm{~kg} / \mathrm{ha}) \text {; } \\
\text { G. Kara cocksfoot; G. Kopu, Aran, G. Prestige white clovers } \\
\text { (1.5 kg/ha each); G. Colenso red clover }(3 \mathrm{~kg} / \mathrm{ha})\end{array}$ & & $\checkmark$ & $\checkmark$ & \\
\hline
\end{tabular}

\section{Measurements}

seasonal herbage accumulation

botanical composition

milk yield

predicted farm milk yield using UDDER

\begin{tabular}{llll}
$\checkmark$ & $\checkmark$ & $\checkmark$ & $\checkmark$ \\
$\checkmark$ & $\checkmark$ & $\checkmark$ & $\checkmark$ \\
& $\checkmark 1$ & & \\
$\checkmark$ & $\checkmark$ & $\checkmark$ & $\checkmark$ \\
\hline
\end{tabular}

${ }^{1}$ Thom et al. (1998) 
simulations, namely, farm area 100 ha; initial (1 July 1996) pasture cover $2000 \mathrm{~kg} \mathrm{DM} / \mathrm{ha}$; initial cow condition score 5.1; 7-week spread of calving beginning 11 July 1996; silage made on $20 \%$ of the farm 1 October15 November; $50 \mathrm{~kg} \mathrm{~N} /$ ha applied in August, April, and June; and pastures topped to remove surplus pasture. Cow stocking rate was calculated from annual HA, using an allowance of $4500 \mathrm{~kg} \mathrm{DM} / \mathrm{cow}$. Replacements were reared on-farm at $20 \%$ of the number of milking cows. The drying-off strategy was variable and determined by trial and error to ensure cow condition score was largely between 4 and 5 , and was not less than 3.5 for more than 1 month. Farm economics were calculated by UDDER assuming $\$ 6.50 / \mathrm{kg}$ milkfat. All simulations were run over 2 years to include carry-over effects on pasture mass and cow condition.

\section{Results}

\section{Pasture production}

On average, water deficit reduced summer HA to 79, 68,43 and $18 \%$ of irrigated controls, and annual HA to $88,80,73$ and $63 \%$ of irrigated controls at the Northland, Waikato, Manawatu, and Canterbury sites, respectively (Table 2). The 3-month (December 1996February 1997) rainfall for Northland, Waikato, Manawatu and Canterbury totalled 400, 170, 217 and $182 \mathrm{~mm}$, respectively; $118 \%, 71 \%, 91 \%$ and $100 \%$ of

Table 2 Seasonal and annual herbage accumulation ( $\mathrm{kg} \mathrm{DM} / \mathrm{ha}$ ) for five pasture types, two water regimes and four sites, (spring = Sep, Oct, Nov, etc) under dairy grazing. Season totals may not equal the annual total owing to rounding and missing data.

\begin{tabular}{|c|c|c|c|c|c|c|}
\hline Site & Pasture type & Spring & Summer & Autumn & Winter & Total \\
\hline \multicolumn{7}{|l|}{ Northland } \\
\hline \multirow[t]{3}{*}{ Dryland } & EP & 3680 & 2640 & 250 & 1440 & 8000 \\
\hline & HER & 2770 & 1060 & 1700 & 2370 & 7900 \\
\hline & TMP & 2201 & 1600 & 2680 & 2300 & 8790 \\
\hline \multirow[t]{6}{*}{ Irrigated } & EP & 3820 & 3690 & 1020 & 1300 & 9840 \\
\hline & HER & 3850 & 830 & 1910 & 2310 & 8900 \\
\hline & TMP & 2810 & 2170 & 2220 & 2190 & 9390 \\
\hline & water & * (123) & ns & ns & ns & ns \\
\hline & pasture type & $* *(151)$ & * (434) & $* * *(152)$ & $* * *(101)$ & ns \\
\hline & interaction & ns & ns & ${ }^{*}(215)$ & ns & ns \\
\hline \multicolumn{7}{|l|}{ Waikato } \\
\hline \multirow[t]{5}{*}{ Dryland } & EP & 1790 & 2590 & 1980 & 1520 & 7870 \\
\hline & HER & 1530 & 2750 & 330 & 1680 & 6290 \\
\hline & TMP & 1890 & 4410 & 1510 & 1400 & 9210 \\
\hline & TM & 1840 & 3530 & 1050 & 1190 & 7610 \\
\hline & LER & 1060 & 2560 & 1510 & 1770 & 6900 \\
\hline \multirow[t]{8}{*}{ Irrigated } & EP & 1640 & 4710 & 1980 & 1900 & 10230 \\
\hline & HER & 1810 & 4810 & 700 & 1760 & 9250 \\
\hline & TMP & 1980 & 5770 & 1130 & 860 & 9710 \\
\hline & TM & 2060 & 4330 & 1070 & 1180 & 8970 \\
\hline & LER & 1480 & 3550 & 1830 & 1670 & 8820 \\
\hline & water & ns & $\dagger(532)$ & ns & ns & $\dagger(803)$ \\
\hline & pasture type & *** $(126)$ & $* * *(323)$ & $* \star *(190)$ & $* * *(122)$ & ** $(468)$ \\
\hline & interaction & ns & ns & ns & ${ }^{*}(277)$ & ns \\
\hline \multicolumn{7}{|l|}{ Manawatu } \\
\hline \multirow[t]{3}{*}{ Dryland } & EP & 5310 & 3190 & 2340 & 2280 & 13120 \\
\hline & HER & 9040 & 2930 & 1270 & 3080 & 16320 \\
\hline & TM & 6330 & 3880 & 1060 & 2480 & 13753 \\
\hline \multirow[t]{6}{*}{ Irrigated } & EP & 4530 & 6860 & 3150 & 2900 & 17440 \\
\hline & HER & 9520 & 6190 & 1820 & 3680 & 21210 \\
\hline & $\mathrm{TM}$ & 5320 & 9900 & 2830 & 2520 & 20580 \\
\hline & water & ns & $* * *(370)$ & ${ }^{*}(250)$ & $* *(70)$ & $* * *(220)$ \\
\hline & pasture type & ${ }^{* * *}(250)$ & ${ }^{*}(460)$ & $\dagger(300)$ & *** $(90)$ & $* * *(270)$ \\
\hline & interaction & ns & ns & ns & $†(120)$ & ${ }^{*}(380)$ \\
\hline \multicolumn{7}{|l|}{ Canterbury } \\
\hline \multirow[t]{3}{*}{ Dryland } & EP & 3220 & 700 & 1660 & 1230 & 6810 \\
\hline & HER & 3350 & 650 & 1820 & 920 & 6740 \\
\hline & LER & 4340 & 860 & 1770 & 990 & 7950 \\
\hline \multirow[t]{6}{*}{ Irrigated } & EP & 3810 & 3630 & 1910 & 790 & 10150 \\
\hline & HER & 4950 & 3550 & 2240 & 945 & 11680 \\
\hline & LER & 4570 & 4990 & 1900 & 1070 & 12530 \\
\hline & water & $* * *(95)$ & $* * *(204)$ & $\dagger(94)$ & ns & ${ }^{* * *}(179)$ \\
\hline & pasture type & $* * *(117)$ & $\dagger(250)$ & ns & ns & $* * *(220)$ \\
\hline & interaction & ${ }^{* *}(165)$ & ns & ns & ns & $\dagger(311)$ \\
\hline
\end{tabular}

ns $\mathrm{P}>0.10,+\mathrm{P}<0.10,{ }^{*} \mathrm{P}<0.05,{ }^{* *} \mathrm{P}<0.01,{ }^{* * *} \mathrm{P}<0.001$, standard error of the mean in parentheses 
average. Carry-over effects of water deficit into autumn and winter occurred only at the Manawatu and Canterbury sites.

Seasonal and annual HA differed between the five pasture types and the four sites. The TM and TMP pastures produced more than the other treatments in autumn in Northland, and in summer in Waikato and Manawatu, but tended to be significantly poorer in spring or winter at these sites (Table 2). The LER pasture averaged $25 \%$ more production in spring and summer in Canterbury, but had below average annual production in Waikato. The kikuyu-based EP in Northland was $120 \%$ more productive than other treatments in summer, but only had $45 \%$ of the production of other treatments in autumn and winter; annual HA was similar to HER and TMP (Table 2).

Water by pasture type interactions occurred in at least one season at each site, and for annual $\mathrm{HA}$ at the Manawatu and Canterbury sites. In Canterbury HER was the most responsive pasture type to irrigation (+73\% compared with $+53 \%$ for other pasture types), but in Manawatu TM was the most responsive pasture type to irrigation $(+50 \%$ compared with $+31 \%$ for other pasture types) (Table 2).

\section{Botanical composition}

The botanical composition of TM, TMP and LER pastures was characterised by high red clover content (15-35\% of pasture mass) at all sites and high white clover content (15-28\% of pasture mass) in Northland, Manawatu and Canterbury. The HER and EP pastures had low $(<10 \%)$ legume content at most sites. Tall fescue content in TM and TMP averaged $14-27 \%$ of HA in January 1997, and timothy content in LER averaged $5-9 \%$ of HA over the same period. The resident pasture in Northland were characterised by high (50$75 \%)$ content of kikuyu during summer and low (5-20\%) content during spring.
Table 3 The number of cows milked per 100 ha, milksolids (kg/ha), gross margin (\$/ ha), and range of cow condition score for five pasture types, two water regimes and four sites, as predicted by UDDER (see Table 1 for a description of the pasture types, Table 2 for the pasture production and the text for a description of the "farm" management).

\begin{tabular}{|c|c|c|c|c|c|}
\hline Site & Pasture type & $\begin{array}{l}\text { Number of } \\
\text { cows milked }\end{array}$ & $\begin{array}{l}\text { Milksolids } \\
\text { kg/ha }\end{array}$ & $\begin{array}{c}\text { Gross margin } \\
\$ / \text { ha }\end{array}$ & $\begin{array}{l}\text { Condition } \\
\text { score }\end{array}$ \\
\hline \multicolumn{6}{|l|}{ Northland } \\
\hline \multirow[t]{3}{*}{ dryland } & EP & 270 & 1024 & $\$ 2781$ & $4.4-5.1$ \\
\hline & HER & 232 & 852 & $\$ 2276$ & $3.6-4.8$ \\
\hline & TMP & 210 & 767 & $\$ 2036$ & $3.5-5.0$ \\
\hline \multirow[t]{3}{*}{ irrigated } & EP & 325 & 1126 & $\$ 2972$ & $3.9-4.8$ \\
\hline & HER & 215 & 768 & $\$ 2026$ & $3.5-4.6$ \\
\hline & TMP & 225 & 800 & $\$ 2105$ & $3.2-4.8$ \\
\hline \multicolumn{6}{|l|}{ Waikato } \\
\hline \multirow[t]{5}{*}{ dryland } & EP & 175 & 637 & $\$ 1676$ & $3.6-5.0$ \\
\hline & HER & 140 & 548 & $\$ 1471$ & $3.3-4.9$ \\
\hline & TMP & 205 & 765 & $\$ 2051$ & $4.0-4.9$ \\
\hline & $\mathrm{TM}$ & 169 & 652 & $\$ 1754$ & $4.1-5.4$ \\
\hline & LER & 153 & 522 & $\$ 1329$ & $3.3-4.9$ \\
\hline \multirow[t]{5}{*}{ irrigated } & EP & 227 & 786 & $\$ 2051$ & $3.3-4.9$ \\
\hline & HER & 202 & 761 & $\$ 2044$ & $3.8-5.2$ \\
\hline & TMP & 216 & 806 & $\$ 2164$ & $3.8-5.1$ \\
\hline & TM & 192 & 749 & $\$ 2034$ & $4.1-5.2$ \\
\hline & LER & 190 & 664 & $\$ 1726$ & $3.4-4.9$ \\
\hline \multicolumn{6}{|l|}{ Manawatu } \\
\hline \multirow[t]{3}{*}{ dryland } & EP & 300 & 1150 & $\$ 3147$ & $3.8-4.6$ \\
\hline & HER & 330 & 1097 & $\$ 2846$ & $4.0-4.5$ \\
\hline & TM & 320 & 1211 & $\$ 3300$ & $4.1-4.6$ \\
\hline \multirow[t]{3}{*}{ irrigated } & EP & 400 & 1430 & $\$ 3835$ & $3.5-4.9$ \\
\hline & HER & 450 & 1638 & $\$ 4432$ & $4.1-4.6$ \\
\hline & TM & 450 & 1544 & $\$ 4079$ & $3.3-4.8$ \\
\hline \multicolumn{6}{|l|}{ Canterbury } \\
\hline \multirow[t]{3}{*}{ dryland } & EP & 142 & 522 & $\$ 1366$ & $3.6-4.7$ \\
\hline & HER & 141 & 502 & $\$ 1294$ & $3.3-4.5$ \\
\hline & LER & 165 & 586 & $\$ 1525$ & $3.4-4.5$ \\
\hline \multirow[t]{3}{*}{ irrigated } & EP & 250 & 921 & $\$ 2471$ & $3.8-5.0$ \\
\hline & HER & 280 & 1094 & $\$ 3009$ & $4.3-5.2$ \\
\hline & LER & 305 & 1120 & $\$ 3016$ & $3.8-5.1$ \\
\hline
\end{tabular}

\section{Modelling}

Predicted farm milk yield obtained using UDDER varied among sites and treatments, but were highly correlated with annual HA (Figure 1). Large differences occurred between sites and water treatments, but differences among pasture types were smaller (Table 3 ). The pattern of milk flow during the season (Figure 2) also varied, with peak milk flow occurring in September and decreasing until drying-off in May. The post-peak rate of decline varied between $6.8 \%$ per month for the Canterbury irrigated LER treatment and 19\% per month for the Manawatu dryland ryegrass treatment (Figure 2).

\section{Discussion}

Large differences in the amount and pattern of herbage accumulation were found among sites, water and pasture type treatments. Establishing new pasture (ryegrass or "alternative" species) often, but not always, improved seasonal or annual HA. Although treatment by site interactions were not tested statistically, the relative performance of resident and established pastures varied among sites.

Water deficit substantially reduced annual HA by an average of $24 \%$ and predicted milksolids yield by an average 
Figure 1 The relationship (and correlation) between farm milksolids production and annual herbage accumulation for five pasture types, two water regimes and four sites (see Tables 1 and 2).

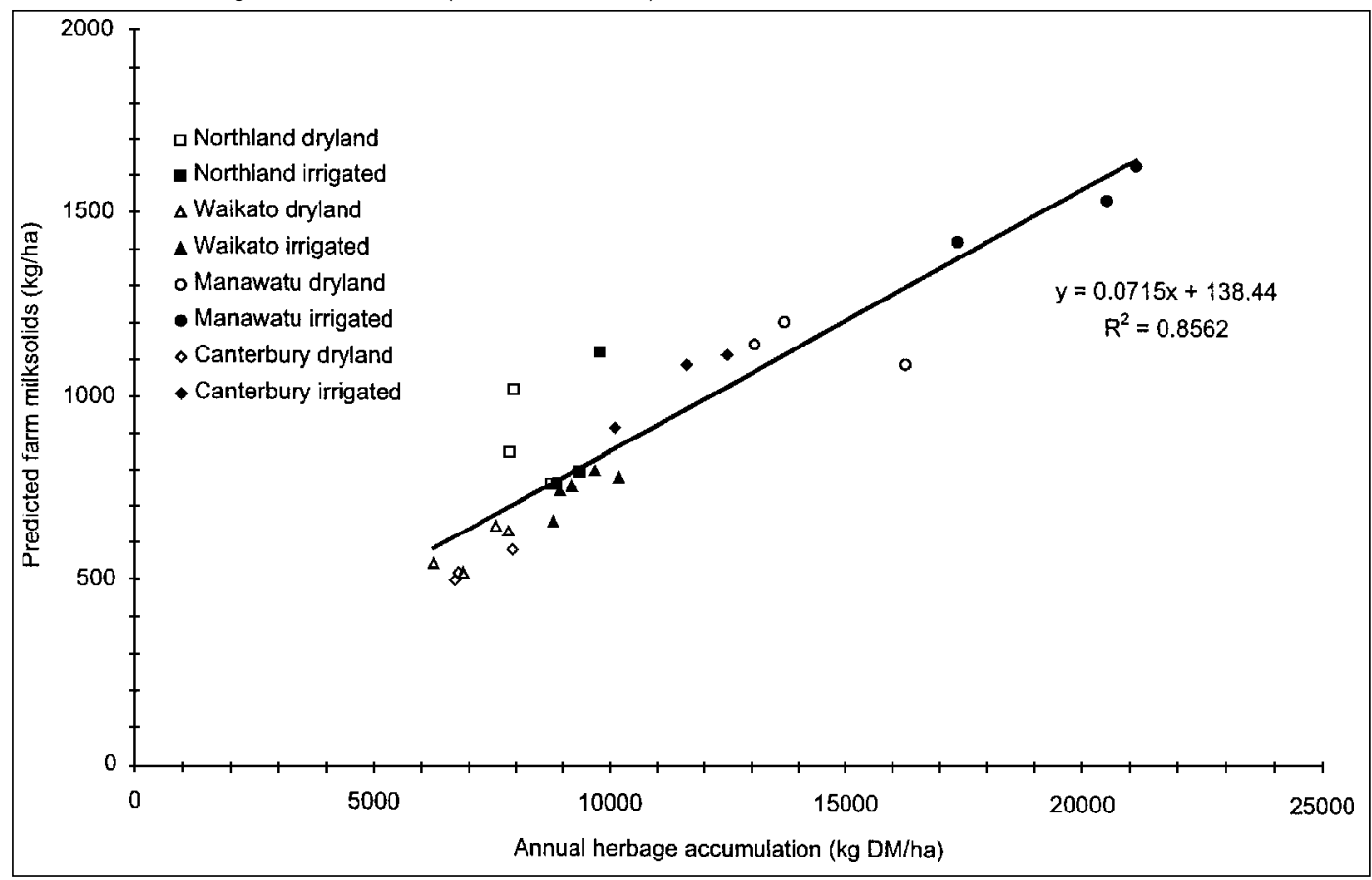

Figure 2 Seasonal milkfat production patterns per 100 ha, predicted by UDDER and regression lines showing the post-peak lost of milk yield for selected pasture types, levels of water, and sites.

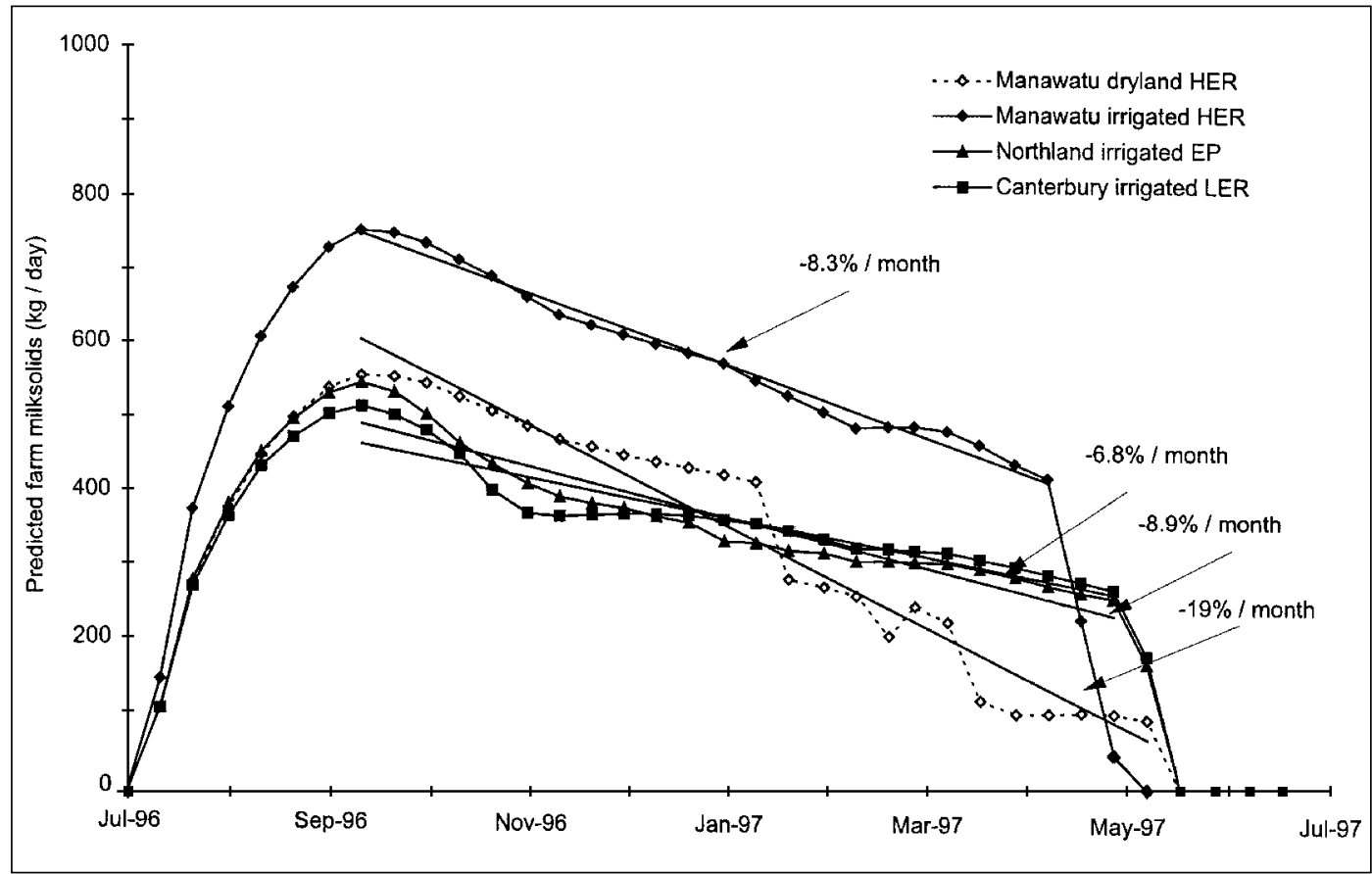


of $21 \%$ across the four sites. At the Northland and Waikato sites the impact of water deficit on predicted milk yield $(-1.9 \%$ and $-6.3 \%$, respectively) was less than for annual HA (-12\% and $-20 \%$, respectively) because most of the milk flow occurred in spring which was unaffected by drought. At the other sites the effects of water deficit on predicted milk flow were similar to the effects on annual HA (-27\% in Manawatu and $-40 \%$ in Canterbury), and this was attributed to water deficit effects occurring over a longer period (i.e., including spring and/or autumn).

Variation in botanical composition among pasture types almost certainly influenced pasture quality to an extent that would affect milk yield per cow (Thom et al. 1998). Although kikuyu in EP at the Northland site likely reduced pasture quality, and the high clover content for LER, TM and TMP at the other sites likely improved pasture quality, these effects were excluded from the modelling exercise. Using the option in UDDER to increase the pasture quality factor by 1.05 (for example, to represent the high clover content of TM and TMP) increased total milk supply but did not appreciably affect the seasonal pattern of milk yield (data not shown). Alternatively, UDDER uses a defined relationship between digestibility and pasture mass to predict effects of pasture quality, and increasing this from $68 \%$ to $83 \%$ for the three months of summer did increase milk yield in summer to the extent that the post-peak decline in milk was reduced from an average $8.8 \%$ (Figure 2) to $6.4 \%$ per month. Although this treatment was arbitrary and had little relationship to realistic management practice, it did illustrate the limited potential for modification of the milk supply pattern using pasture quality alone.

Differences in shape of the milk supply curve for various treatments did occur. However, unless this was the result of early drying-off, the loss in monthly milksolids production usually was approximately $8 \%$ per month, despite quite large differences in the seasonal growth patterns of pasture treatments. Although this lack of response might be an artefact of UDDER, it was concluded that the inherent decline of milk yield during lactation is relatively insensitive to improvements in forage supply. There is likely to be difficulty in achieving a dairy industry goal of $4 \%$ per month post-peak decline of farm milk yield through forage alone. Any modifications to the summer milk production pattern might need to be associated with out-of-season calving, some compromise of peak milk yield, or more dramatic changes in feed quantity and quality than occurred for the treatments in this study.

\section{ACKNOWLEDGEMENTS}

Alan and Owen Greig, Selwyn Gardner and Kevin Baxter are thanked for providing land, fencing and stock; Brenda Stuart, Ray Moss, Deanne Waugh, Helen Simons, Roslyn McCabe, Elizabeth Grayling, and staff of the Grasslands Herbage Lab are thanked for technical assistance; funded by FRST contracts C10532, C10826 and DRC602.

\section{REFERENCES}

McAneney, K.J.; Judd, M.J.; Weeda, W.C. 1982. Loss in monthly pasture production resulting from dryland conditions in the Waikato. New Zealand journal of agricultural research 25: 151-156.

Larcombe, M.T. 1990. UDDER-8 A Desktop Dairy Farm for Extension and Research - Operating Manual (C) WPC Computing.

Lambert, J.P. 1967. Pasture species for Northland. Proceedings of the New Zealand Grassland Association 29: 78-87.

Milne, G.D.; Shaw, R.; Powell, R.; Pirie, B.; Pirie, J. 1997. Tall fescue on dairy farms. Proceedings of the New Zealand Grassland Association 59: 163169.

Parfitt, R.L.; Roberts, A.H.C.; Thomson, N.A.; Cook, F.J. 1985. Water use, irrigation and pasture production on Stratford silt loam. New Zealand journal of agricultural research 28: 393-401.

Thom, E.R.; Clark, D.A.; van Vught, V.T.; Waugh, C.D. 1998. Pasture species and drought impact on milk yield 1. Milk yield responses in the Waikato. Proceedings of the New Zealand Grassland Association 60: 39-44. 